\title{
Comparative Analysis of Indices in the Study of Virulence Diversity Between and Within Populations of Puccinia recondita f. sp. tritici in Israel
}

\author{
J. Manisterski, Z. Eyal, P. Ben-Yehuda, and E. Kosman
}

\begin{abstract}
All authors: Institute for Cereal Crops Improvement (ICCI), The George S. Wise Faculty for Life Sciences; second author: Department of Plant Sciences, The George S. Wise Faculty for Life Sciences; fourth author: School of Mathematical Sciences, The Raymond and Beverly Sackler Faculty of Exact Sciences, Tel Aviv University, Tel Aviv 69978, Israel.

Z. Eyal is deceased.
\end{abstract}

Accepted for publication 25 January 2000.

\begin{abstract}
Manisterski, J., Eyal, Z., Ben-Yehuda, P., and Kosman, E. 2000. Comparative analysis of indices in the study of virulence diversity between and within populations of Puccinia recondita f. sp. tritici in Israel. Phytopathology 90:601-607.

Isolates of Puccinia recondita f. sp. tritici $(n=260)$ obtained from bread, durum, and wild emmer wheat leaf collections throughout Israel during 1993 to 1997 were analyzed for virulence on a set of wheat differentials. The overall frequency of virulence increased on differentials possessing resistance genes $L r 1, L r 2 a, L r 3$, and $L r 26$ and decreased on Lr17, Lr21, and Lr30. Genes Lr9 and Lr24 were resistant, while Lr18 was susceptible ( $98 \%$ in 1996) to all tested leaf rust isolates and $L r 10$ and

degrees of similarity among distinct phenotypes) and $H_{\mathrm{KDis}}$ (based on frequencies of individual virulences) and Nei's and Rogers' distances. The greatest difference occurred between the 1993 and 1994 populations. Phenotypic diversity within each population (year) was analyzed using the Shannon's, Simpson's, and Kosman's indices. The highest diversity within years was recorded in 1994 and significantly increased from 1993 to 1994 for all indices. The variance in the diversity between populations can be only partially explained by differences between corresponding diversities within population. The comparative analysis of diversity between and within populations over the 5 years enabled a detailed study of changes in the pathogen population. The results show that the different measures do not yield the same rank order of diversity.
\end{abstract} Lr23 were susceptible to more than $78 \%$ of the isolates. Diversity between populations (years) was assessed using Kosman's $H_{\mathrm{KB}}$ (based on

Wheat leaf rust, caused by Puccinia recondita Roberge ex Desmaz. f. sp. tritici, occurs annually throughout most wheat-growing areas of Israel. The indigenous populations of wheat relatives, Aegilops spp. and wild emmer (Triticum turgidum var. dicoccoides Koern. in Schweinf., $2 n=28$, genome AABB) harbor leaf rust, but their contribution to the onset of disease and diversity in virulence is unknown (22). Leaf rusts on Aegilops spp. in Israel have their sexual state on plants from the Boraginaceas family rather than on Thalictrum spp. (Ranunculaceae), and are not pathogenic on common wheat ( $T$. aestivum L., $2 n=42$, genome AABBDD) (1). A leaf rust was recently collected from an indigenous $T$. (Aegilops) speltoides $(2 n=14$, genome $\mathrm{SS})$ population in northern Israel that was capable of infecting Thalictrum spp. but not seedlings of common and durum (T. turgidum var. durum Desf., $2 n=28$, genome AABB) wheat (20). The majority of the commercial common and durum wheat cultivars grown in Israel carry CIMMYT (International Maize and Wheat Improvement Center, Mexico D.F.) germ plasm with variable levels of resistance to local leaf rust races. In Israel changes in wheat cultivars are rather slow, and not a single cultivar was withdrawn or added during the 5 years of sampling. Under such conditions, the Israeli wheat-leaf rust pathosystem is probably in balance, with some fluctuations within and between years.

The phenotypic or genetic diversity between populations of rust races collected in race surveys were analyzed to compare the effects of years $(7,8,10)$, assess the impact of field versus nursery

Corresponding author: J. Manisterski, E-mail address: cereal@ post.tau.ac.il

Publication no. P-2000-0403-01R

(C) 2000 The American Phytopathological Society
Additional keywords: leaf rust, Triticum spp. collections, measure regional and local diversity (15-17,31), and assess phenotypic diversity within populations and phenotypic overlap between populations (10).

Nei's genetic distance between populations (25) and Rogers' index of genetic similarity and distance (28) were used to reveal differences between populations. Leonard et al. (12) had used these measures to calculate diversity of virulence among populations of $P$. recondita f. sp. tritici collected from different areas in the United States. Rogers' index provides a comparison between two populations on the basis of the frequencies of the phenotypes that occur in the populations, regardless of how many virulence factors the phenotypes share. The Rogers' index, therefore, does not account for close similarities of pathogen phenotypes that may differ from one another only by one or a few responses. Nei's distance, on the other hand, when applied to plant pathogens, measures frequencies of individual virulence irregardless of phenotype. Leonard et al. (12) questioned the use of these diversity measures in assessing the degrees of genetic differences among populations of asexually reproducing rust fungi and suggested the use of both simultaneously.

Shannon-Weaver's (29) and Simpson's (30) indices were used to measure genetic diversity within populations (i.e., year, continent, region, and location). They are calculated based on occurrence and frequency of races in each population. These indices consider nonidentical phenotypes as equally distinct and ignore the number of differences in virulence between isolates. Nevertheless, some isolates exhibit distinct response patterns, while others are quite similar.

Recently, Kosman suggested two new analyses for assessing genetic variation between and within populations that take into account both phenotypic frequencies and degrees of similarity among 
distinct phenotypes (11). These indices were not assessed previously or analytically compared with other indices using actual data.

The objectives of this study were to (i) describe the variations in virulence of $P$. recondita $\mathrm{f}$. $\mathrm{sp}$. tritici populations in Israel during 1993 to 1997, (ii) apply new analytical tools to examine the variation of actual data on a fixed set of differentials, and (iii) compare different diversity indices.

\section{MATERIALS AND METHODS}

Leaf rust uredinial collections were made from commercial spring common and durum wheat cultivars and from wild emmer. Each year leaf samples were collected from the same regions across Israel and in constant proportions during 1993 to 1997 , according to common practice in such studies $(15-17,24)$. Urediniospores from each collection were used to inoculate 10-day-old seedlings of a susceptible local wheat cultivar.

Leaf rust isolates and wheat genotypes. A total of 260 single urediniospore isolates was analyzed, with 40 isolates collected in 1993, 60 each in 1994 and 1995, and 50 each in 1996 and 1997. Isolates were handled and increased according to Long et al. (17). The majority of the analyzed isolates $(63.5 \%)$ were of common wheat origin, and the rest of the isolates originated from T. turgidum. Urediniospores of each isolate were inoculated on a differential host series consisting of 17 wheat single-gene isolines known to possess resistance genes $(\mathrm{Lr}) \mathrm{l}, 2 \mathrm{a}, 2 \mathrm{c}, 3,3 \mathrm{ka}, 9,10,11$, $15,16,17,18,21,23,24,26$, and 30 in a Thatcher genetic background $(2,4-6,13,27)$. After a 12-h moist period, inoculated differentials were placed in a temperature-controlled greenhouse $(20 \pm$ $2{ }^{\circ} \mathrm{C}$ ) and recorded 12 to 14 days later as either high- or low-infection types. Virulence patterns were assigned according to Long and Kolmer (13), with the addition of a fourth differential set ( $\operatorname{rr10}, 18,21$, and 23) and $\operatorname{Lr15}$, which was found earlier as a differentiating gene.

Data analysis. The frequency of virulence was calculated for each year. Of 60 isolates, 10 random samples (sampling with replacement) were drawn per population (year) for each of the 5 years for the purposes of statistical analysis. Diversity indices, distances, and their statistics were calculated from occurrence and frequency of virulence for these random samples. Comparative analysis was conducted for diversities within and between populations (years). The effect of difference in diversity within populations on the distance between populations was estimated.

Diversity between populations. Diversity was estimated by Rogers' index (28) and Kosman's (11) and Nei's (25) distances.
The frequency of virulence on a specific isoline is treated as the frequency of the allele for virulence corresponding to the resistance gene on that isoline. Rogers' index (28) provides a comparison between two populations on the basis of the frequencies of phenotypes that occur in the populations, regardless of how many shared virulences occur. Rogers' index varies from 0, for two populations with identical response structure, to 1 , for populations with no common phenotypes.

Nei's standard genetic distance (25) measures the difference between two populations on the basis of frequencies of alleles at a number of genetic loci regardless of phenotype. In rust surveys, the frequencies of individual virulence factors rather than gene frequencies are determined. Nei's distance values vary between 0 , when two populations have identical frequencies of alleles over all loci tested, and infinity, if two populations share no alleles.

Kosman's $H_{\mathrm{KB}}$ distance was developed in 1996 and is referred to as the $K$ distance (11). It takes into account both phenotypic frequencies and degrees of similarity among distinct phenotypes. If the samples of isolates from the two populations are phenotypically identical, then $H_{\mathrm{KB}}=0$; if the samples are different, then $0<$ $H_{\mathrm{KB}} \leq 1$.

A new distance $\left(H_{\mathrm{KDis}}\right)$ between populations $X$ and $Y$ has been created. It is based on frequencies of individual virulences:

$$
H_{\mathrm{KDis}}(X, Y)=\frac{1}{k} \sum_{i=1}^{k}\left|p_{X i}-p_{Y i}\right|
$$

where $p_{X i}$ and $p_{Y i}$ are virulence frequencies on differential $i$ in populations $X$ and $Y$, respectively, and $k$ is the total number of differentials being tested. This distance was independently developed by Long et al. (14). Values of the $H_{\mathrm{KDis}}$ distance may vary between 0 , when the two populations have identical frequencies of virulence over all the differentials tested, and 1, if the two populations share no common avirulence/virulence $\left(p_{X i}=1\right.$ and $p_{Y i}=0$ or $p_{X i}=0$ and $p_{Y i}=1$ for each $\left.i=1,2, \ldots, k\right)$. The new distance $H_{\mathrm{KDis}}$ can be used instead of Nei's distance because both are calculated on the basis of virulence frequencies, but $H_{\mathrm{KDis}}$ is more suitable for comparing plant-pathogen populations (14). $H_{\mathrm{KDis}}$ also is easily compared with the $H_{\mathrm{KB}}$ distance, $0 \leq H_{\mathrm{KDis}} \leq H_{\mathrm{KB}} \leq 1$. Any discrepancy between $H_{\mathrm{KB}}$ and $H_{\mathrm{KDis}}$ may reflect a character of differences between the two populations.

Diversity within population. Simpson's (30) and ShannonWeaver's (29) diversity indices $\left(H_{\mathrm{SI}}\right.$ and $H_{\mathrm{SW}}$, respectively) are based on the relative frequencies of different phenotypes; however, they consider nonidentical phenotypes as equally distinct and ignore the

TABLE 1. Frequency of virulence of Puccinia recondita f. sp. tritici isolates collected during 1993 to 1997 in Israel on wheat test lines carrying single genes for resistance to leaf rust $(L r)$

\begin{tabular}{|c|c|c|c|c|c|c|c|}
\hline \multirow[b]{2}{*}{$L r$ gene } & \multirow[b]{2}{*}{ Source } & \multirow[b]{2}{*}{ Test line ${ }^{a}$} & \multicolumn{5}{|c|}{ Frequency of virulence $(\%)$} \\
\hline & & & 1993 & 1994 & 1995 & 1996 & 1997 \\
\hline 1 & Malakof & RL6003 & 35.0 & 78.3 & 58.3 & 62.0 & 62.0 \\
\hline $2 a$ & Webster & RL6016 & 2.5 & 25.0 & 40.0 & 24.0 & 28.0 \\
\hline $2 c$ & Brevit & RL6047 & 67.5 & 50.0 & 50.0 & 82.0 & 78.0 \\
\hline 3 & Democrat & RL6002 & 35.0 & 78.3 & 63.3 & 62.0 & 76.0 \\
\hline $3 k a$ & Klein Aniversario & RL6007 & 22.5 & 18.3 & 13.3 & 24.9 & 38.0 \\
\hline 9 & Triticum umbellulatum & RL6010 & 0.0 & 0.0 & 0.0 & 0.0 & 0.0 \\
\hline 10 & Lee & RL6004 & 100.0 & 78.3 & 100.0 & 100.0 & 98.0 \\
\hline 11 & Hussar & RL6053 & 0.0 & 13.3 & 3.3 & 18.0 & 6.0 \\
\hline 15 & Kenya 1-12 E-19-J & RL6052 & 0.0 & 28.3 & 3.3 & 0.0 & 0.0 \\
\hline 16 & Exchange & RL6005 & 32.5 & 60.0 & 60.0 & 70.0 & 62.0 \\
\hline 17 & Klein Lucero & RL6008 & 20.0 & 28.3 & 11.7 & 0.0 & 16.0 \\
\hline 18 & Africa 43 & RL6009 & 100.0 & 100.0 & 100.0 & 98.0 & 100.0 \\
\hline 21 & Triticum tauschii & RL6043 & 10.0 & 11.7 & 1.7 & 2.0 & 14.0 \\
\hline 23 & Gabo & RL6012 & 100.0 & 96.7 & 100.0 & 94.0 & 96.0 \\
\hline 24 & Agropyron elongatum & RL6064 & 0.0 & 0.0 & 0.0 & 0.0 & 0.0 \\
\hline 26 & Imperial rye & RL6078 & 2.5 & 25.0 & 48.3 & 32.0 & 50.0 \\
\hline 30 & Terenzio & RL6049 & 30.0 & 46.7 & 11.7 & 30.0 & 36.0 \\
\hline Number of pathotypes & $\ldots$ & $\ldots$ & 11 & 23 & 14 & 16 & 15 \\
\hline Number of isolates & $\ldots$ & $\ldots$ & 40 & 60 & 60 & 50 & 50 \\
\hline
\end{tabular}

a Wheat single-gene isolines known to possess $L r$ resistance genes. 
response patterns of the isolates. When a given set of phenotypes is prescribed, they assign maximum diversity to a population that is divided equally among them (property 2) (7), and, if the number of phenotypes is different and the phenotypes within each population are equally distributed, the higher diversity index is assigned to the population with more phenotypes.

A new index $\left(H_{\mathrm{KDiv}}\right)$ was developed to estimate diversity within a population. It is based on the frequencies of individual virulence factors. If $p_{i}$ is the virulence frequency of a given population on differential $i$, then the population diversity with respect to this differential can be calculated as the minimal value between $2 p_{i}$ and $2\left(1-p_{i}\right), \min \left[2 p_{i}, 2\left(1-p_{i}\right)\right]$. This diversity index ranges from 0 to 1: maximal diversity is assigned when $p_{i}=1-p_{i}=1 / 2$, and the minimal value is obtained when $p_{i}=0$ or 1 . The new diversity index of a given population is defined as a mean value of individual diversities over all tested differentials:

$$
H_{\mathrm{KDiv}}=\frac{1}{k} \sum_{i=1}^{k} \min \left[2 p_{i}, 2\left(1-p_{i}\right)\right]
$$

where $k$ is the total number of differentials. Values for this index range from 0 to $1: H_{\mathrm{KDiv}}=0$ for a population that is limited to a single phenotype and $H_{\mathrm{KDiv}}=1$ for a population with frequency 0.5 of each individual virulence over the set of differentials used.

The $H_{\mathrm{KW}}$ (also referred to as Ko) diversity index of a pathogen population was proposed by Kosman (11). It ranges from 0 to 1; $H_{\mathrm{KW}}=0$ for a population that is limited to a single phenotype. The maximal diversity score is assigned to a population which consists of pairs of isolates with absolutely different response patterns on the entire set of differentiating factors (i.e., wheat differentials). This index preserves some of the properties of Simpson's and Shannon's indices, but not all of them (11). $H_{\mathrm{KW}}$ takes into account the contribution of similarity and dissimilarity among isolates to the diversity within a population, not only the relative frequencies of different phenotypes. On the other hand, $H_{\mathrm{KW}}$ considers a population as a set of different phenotypes with possibly associated virulence and avirulence and does not characterize a population by an independent set of virulence frequencies (in contrast to $H_{\mathrm{KDiv}}$ ). The $H_{\mathrm{KW}}$ and $H_{\mathrm{KDiv}}$ diversity indices are easily compared: $0 \leq H_{\mathrm{KW}} \leq H_{\mathrm{KDiv}} \leq 1$. Any discrepancy between $H_{\mathrm{KW}}$ and $H_{\mathrm{KDiv}}$ may reflect the overall relationships between different virulences (genes) in the population.

\section{RESULTS}

Frequency of virulence. The frequency of virulence of the 260 leaf samples collected in Israel during 1993 to 1997 from seed- lings of the Thatcher isolines is presented in Table 1. $\operatorname{Lr}$ genes 9 and 24 were resistant to all leaf rust isolates, whereas $L r$ genes 10 , 18 , and 23 were susceptible to most isolates. The number of collections from common wheat greatly exceeded that of durum and wild emmer origin. The number of pathotypes was higher in 1994 $(n=23)$ than in $1993(n=11), 1995(n=17), 1996(n=16)$, and $1997(n=15)$, with the majority of pathotypes collected from common wheat. The virulence patterns of $P$. recondita $\mathrm{f}$. $\mathrm{sp}$. tritici, given in unified numbers (13), during 1993 to 1997 on leaf rust wheat differentials are presented in Table 2. Races with more virulence on $L r$ genes, such as $P$. recondita f. sp. tritici types RGMR and THBR, (uniform number [UN] races 13 and 6, respectively), were sampled mainly from common wheat, whereas most durum isolates were BBBR or DBBR (UN races 1 and 10, respectively). The pathogen population on common wheat was more complex than on the durum wheat population. The most prevalent types were BBBR, DBBR, PGMR, and THBR, although the number of common races between pairs of years was small (ranging from two to four), except between 1994 and 1996 (six common races).

The small number of common races is indicative of considerable differences among the five populations-years in Israel. The virulence of the durum collections is greatly influenced by the very few durum wheat cultivars grown in Israel, all of CIMMYT origin, and by local durum land races. The frequency of virulence on resistance genes $L r 1, L r 2 a, L r 3, L r 16$, and, especially, Lr26 increased to moderate to high levels (Table 1). Resistance genes $L r 3 k a, L r 11, L r 15, L r 17$, and $L r 21$ were effective against isolates collected during the years of the survey. Overall, equal frequencies were obtained on certain $\mathrm{Lr}$ genes (i.e., $35.0 \%$ on $\mathrm{Lrl}$ and $\mathrm{Lr} 3$ in 1993; 78.3\% on $\mathrm{Lrl}, \mathrm{Lr3}$, and $\mathrm{LrlO}$ in 1994; $62 \%$ on $\mathrm{Lrl}$ and $\mathrm{Lr3}$ in 1996; and 3.3\% on $L r l 1$ and $L r 15$ and $11.7 \%$ on $L r 17$ and $L r 30$ in 1995). Frequency increased on Lr17 and Lr21 from 1996 to 1997. A previously undetected virulence pattern (CCDR) appeared in 1995 and again in 1997, with virulence on $\operatorname{Lr} 3,10,17,18,23$, and 26 on previously resistant commercial spring wheat cvs. Atir (CNO"S"/PJ/4/GLL/3/TOB//JAR"S"/CRESPO) and Dariel (HORK/ YMH//KAL/BB, CM38212-) (Hazera Seed Co., Sde-Gat, Israel.

Diversity within populations. The calculations of the diversity indices were based on 15 of 17 differentials. Resistance genes $\operatorname{Lr} 9$ and $L r 24$ were excluded because they were highly resistant, to all 260 isolates. The diversity in virulence spectra within each population-year was calculated using Kosman's $\left(H_{\mathrm{KW}}\right.$ and $\left.H_{\mathrm{KDiv}}\right)$, Shannon-Weaver's, and Simpson's indices (Table 3 ). These indices are mean values calculated on the basis of 10 random samples. The mean values were compared according to two-sample $t$ tests at the $\alpha=0.05$ level. Shannon-Weaver's and Simpson's indices were

TABLE 2. Virulence patterns of Puccinia recondita f. sp. tritici in Israel during 1993 to 1997

\begin{tabular}{|c|c|c|c|c|c|c|c|c|c|c|c|}
\hline \multirow[b]{2}{*}{$\mathrm{UN}_{\text {race }}{ }^{\mathrm{a}}$} & \multirow{2}{*}{$\begin{array}{l}\text { Total } \\
\text { no. of } \\
\text { types }^{b}\end{array}$} & \multicolumn{2}{|c|}{$1993(40)^{\mathrm{c}}$} & \multicolumn{2}{|r|}{$1994(60)$} & \multicolumn{2}{|r|}{$1995(60)$} & \multicolumn{2}{|c|}{$1996(50)$} & \multicolumn{2}{|r|}{$1997(50)$} \\
\hline & & $\begin{array}{l}\text { No. of } \\
\text { types }^{d}\end{array}$ & $\begin{array}{l}\text { Prevailing } \\
\text { type }^{\mathrm{e}}\end{array}$ & $\begin{array}{l}\text { No. of } \\
\text { types }\end{array}$ & $\begin{array}{c}\text { Prevailing } \\
\text { type }\end{array}$ & $\begin{array}{l}\text { No. of } \\
\text { types }\end{array}$ & $\begin{array}{c}\text { Prevailing } \\
\text { type }\end{array}$ & $\begin{array}{l}\text { No. of } \\
\text { types }\end{array}$ & $\begin{array}{c}\text { Prevailing } \\
\text { type }\end{array}$ & $\begin{array}{l}\text { No. of } \\
\text { types }\end{array}$ & $\begin{array}{l}\text { Prevailing } \\
\text { type }\end{array}$ \\
\hline UN1 (B) & 5 & 1 & BBBR (11/11) & 3 & $\operatorname{BBBR}(7 / 9)$ & 3 & BBBR (16/19) & 1 & $\operatorname{BBBR}(6 / 6)$ & 2 & BBBR (3/4) \\
\hline UN2 (C) & 5 & $\ldots$ & $\ldots$ & $\ldots$ & $\ldots$ & 2 & CCDR (3/4) & $\ldots$ & $\ldots$ & 4 & CCDR (4/7) \\
\hline UN10 (D) & 3 & 2 & DBBR (14/15) & 2 & DGBR (3/4) & 1 & $\operatorname{DBBR}(1 / 2)$ & 3 & $\begin{array}{l}\text { DBBR (7/13), } \\
\text { DGBR (4/13) }\end{array}$ & 2 & $\begin{array}{l}\operatorname{DBBR}(5 / 8), \\
\operatorname{DGBR}(3 / 8)\end{array}$ \\
\hline UN11 (L) & 1 & $\ldots$ & $\ldots$ & $\ldots$ & $\ldots$ & 1 & $\operatorname{LCBR}(1 / 1)$ & $\ldots$ & $\ldots$ & $\ldots$ & $\ldots$ \\
\hline UN5 (M) & 17 & 2 & $\begin{array}{l}\operatorname{MBMT}(1 / 2), \\
\operatorname{MGBR}(1 / 2)\end{array}$ & 12 & MBDH $15(7 / 21)$ & 4 & $\operatorname{MGBR}(2 / 5)$ & 3 & $\operatorname{MGBR}(1 / 3)$ & $\cdot$ & $\cdots$ \\
\hline UN6 (P) & 26 & 9 & PGMR (3/11) & 9 & PGMR (3/11) & 5 & PGBR $(1 / 5)$ & 10 & $\begin{array}{l}\text { PGBR (4/16), } \\
\text { PGMR (4/16) }\end{array}$ & 7 & $\begin{array}{l}\text { PGMR (5/12), } \\
\text { PGMT (2/12) }\end{array}$ \\
\hline UN7 (R) & 1 & $\ldots$ & $\ldots$ & $\ldots$ & $\ldots$ & 1 & RHMR (1/1) & $\ldots$ & $\ldots$ & $\ldots$ & $\ldots$ \\
\hline UN13 (T) & 19 & 1 & TGPT (1/1) & 12 & $\begin{array}{l}\text { THCR }(3 / 15), \\
\text { TGMT }(2 / 15)\end{array}$ & 9 & $\begin{array}{l}\text { THBR }(12 / 23), \\
\operatorname{THDR}(3 / 23)\end{array}$ & 3 & $\begin{array}{l}\text { THBR }(6 / 12), \\
\text { THGR }(4 / 12), \\
\text { THMR }(2 / 12)\end{array}$ & 7 & $\begin{array}{l}\text { THBR (10/19), } \\
\operatorname{TGMR}(3 / 19), \\
\operatorname{THMR}(2 / 19)\end{array}$ \\
\hline
\end{tabular}

\footnotetext{
${ }^{\text {a }}$ Unified number races containing leaf rust $(L r)$ resistance genes $1,2 a, 2 c$, and 3 .

b Total number of $P$. recondita $\mathrm{f}$. sp. tritici types.

c Numbers in parentheses indicate numbers of isolates.

d Number of $P$. recondita f. sp. tritici types.

e Number of isolates per UN class is given in parentheses.
} 
statistically different for each paired comparison between 1993 and 1997. The highest diversity was recorded for the 1994 population and the lowest for the 1993 population for all indices. The next most diverse population according to Shannon-Weaver's $\left(H_{\mathrm{SW}}\right)$ and Simpson's $\left(H_{\mathrm{SI}}\right)$ indices was the 1996 population. This rank was assigned to the 1995 population by the $H_{\mathrm{KW}}$ and $H_{\mathrm{KDiv}}$ indices. According to $H_{\mathrm{KW}}$ and $H_{\mathrm{KDiv}}$, no statistical differences were observed between the 1996 and 1997 populations.

The relationships between the indices of diversity within populations-years are presented in Table 4. The correlation between the four indices for the overall diversity for the five populations-years was highest (>0.95) between $H_{\mathrm{KW}}$ and $H_{\text {KDiv }}$ and between Shannon-Weaver's $\left(H_{\mathrm{SW}}\right)$ and Simpson's $\left(H_{\mathrm{SI}}\right)$ indices. Shannon-Weaver's and Simpson's diversity indices were highly correlated, possibly because both are based on race (phenotype) frequencies. Low correlation between $H_{\mathrm{KDiv}}$ and Shannon-Weaver's and Simpson's indices for most years, except 1993, was expected, because the former diversity index is based on virulence frequencies, whereas $H_{\mathrm{SW}}$ and $H_{\mathrm{SI}}$ are based on frequencies of phenotypes. However, in 1993 correlations between $H_{\mathrm{KDiv}}$ and $H_{\mathrm{SI}}$ and $H_{\mathrm{KDiv}}$ and $H_{\mathrm{SW}}$ were relatively high (0.907 and 0.919, respectively). Therefore, in 1993 more than $82 \%$ of the variance of diversity of race structure (variance of $H_{\mathrm{SI}}$ or $H_{\mathrm{SH}}$ ) can be explained by the mean value of diversities in individual virulences (value of $H_{\mathrm{KDiv}}$ ).

The $H_{\mathrm{KW}}$ diversity index takes into account both the frequencies of individual virulence and race frequencies. High correlation between $H_{\mathrm{KW}}$ and $H_{\mathrm{KDiv}}$ in 1994, 1995, 1996, and 1997 (Table 4) means that the former was influenced mainly by the virulence frequencies. Low level of correlation between $H_{\mathrm{KW}}$ and the ShannonWeaver's or Simpson's indices for the same populations (years) indicates that the influence of race frequencies on $H_{\mathrm{KW}}$ was minimal. The high correlation between $H_{\mathrm{KW}}$ and $H_{\mathrm{KDiv}}$ and between $H_{\mathrm{KW}}$ and Shannon-Weaver's and Simpson's indices in $1993 \mathrm{im}-$ plies that $H_{\mathrm{KW}}$ was, in this case, nearly equally influenced by virulence frequencies and race frequencies.

TABLE 3. Diversity within populations (years) of Puccinia recondita f. sp. tritici in Israel during 1993 to 1997, calculated based on Shannon-Weaver's $\left(H_{\mathrm{SW}}\right)$, Simpson's $\left(H_{\mathrm{SI}}\right)$, and Kosman's $\left(H_{\mathrm{KW}}\right.$ and $\left.H_{\mathrm{KDiv}}\right)$ indices $^{\mathrm{a}}$

\begin{tabular}{lllll}
\hline Year & $H_{\mathrm{SW}}$ & $H_{\mathrm{SI}}$ & $H_{\mathrm{KW}}$ & $H_{\mathrm{KDiv}}$ \\
\hline 1993 & 1.889 & 0.787 & 0.305 & 0.391 \\
1994 & 2.969 & 0.938 & 0.450 & 0.574 \\
1995 & 2.147 & 0.826 & 0.388 & 0.496 \\
1996 & 2.607 & 0.913 & $0.357^{*}$ & $0.458^{*}$ \\
1997 & 2.466 & 0.897 & $0.367^{*}$ & $0.475^{*}$ \\
\hline
\end{tabular}

a $*$ indicates no significant statistical difference between marked years at $\alpha=$ 0.05 according to two sample $t$ test.
Diversity between populations. Four indices of diversity between populations (distances)—Nei's, Rogers', and Kosman's $H_{\mathrm{KB}}$ and $H_{\mathrm{KDis}}$ distances-were calculated for all possible paired comparisons of the five populations-years (Table 5). The indices are mean values calculated on the basis of 10 paired random samples. According to Nei's distance, the greatest difference occurs between the 1993 and 1997 populations, with less diversity between 1993 and 1996 and 1994 and 1995 and the lowest diversity between 1995 and 1996. The greatest value of the Nei's distance was statistically indistinguishable, based on two-sample $t$ tests at the $\alpha=0.05$ level, with distances recorded between 1994 and 1997 and 1996 and 1997, all ranging from 0.077 to 0.081 . The greatest distance assigned by the Rogers' index was recorded between 1994 and 1997 and the lowest between 1993 and 1996. The highest $H_{\mathrm{KB}}$ values were recorded between 1993 and 1994 and somewhat lower distances between 1993 and 1997 and 1994 and 1997. The lowest distances were recorded between 1993 and 1996 and 1995 and 1996. The highest $H_{\mathrm{KDis}}$ distance was recorded between 1993 and 1994 and the lowest between 1995 and 1996 and 1995 and 1997.

The relationships between the four distances are presented in Table 6. The Pearson correlation values for the distances for all paired comparisons between the five years (1993 to 1997) were highest between the $H_{\mathrm{KB}}$ and $H_{\mathrm{KDis}}$ distances. The correlation between the Rogers' index and Nei's distance or $H_{\mathrm{KDis}}$ were relatively low. This means that possible changes in race structure are not necessarily explained by changes in the virulence frequencies of a population. Relatively high correlation between $H_{\text {KDis }}$ and Nei's distance can be explained by the nature of these two indices, because both are based on virulence frequencies. The $H_{\mathrm{KB}}$ distance between populations was highly correlated with $H_{\mathrm{KDis}}$ and Nei's distance, whereas the correlation between $H_{\mathrm{KB}}$ and Rogers' index was very low (except for 1993 versus 1994 to 1997). This means that $H_{\mathrm{KB}}$, which is based on both virulence and race frequencies, was influenced mainly by virulence frequencies, whereas Rogers' index was based on race frequencies. The relatively high correlations between $H_{\mathrm{KB}}$ and Nei's and Rogers' distances in comparisons between 1993 versus 1994, 1995, 1996, and 1997 imply that the $H_{\mathrm{KB}}$ distance was equally influenced by virulence and race frequencies.

If two populations are compared, it is possible that differences between them can be explained only by the difference in measure of diversity within each population. For example, if two populations, $X$ and $Y$, are characterized by means $\mu_{1}$ and $\mu_{2}$ and variances $\sigma_{1}^{2}$ and $\sigma_{2}^{2}$ for any parameter, respectively, then the distance between these populations can be defined by the function $d(X, Y)=\left|\mu_{1}-\mu_{2}\right|+$ $\left|\sigma_{1}^{2}-\sigma_{2}^{2}\right|$, where $\sigma_{1}^{2}$ and $\sigma_{2}^{2}$ reflect diversities within populations $X$ and $Y$, respectively. The populations are different, namely $d(X, Y) \neq$ 0 , even if $\mu_{1}=\mu_{2}$ but $\sigma_{1}^{2} \neq \sigma_{2}^{2}$ Therefore, the question of whether

TABLE 4. Correlation coefficients between Shannon-Weaver's $\left(H_{\mathrm{SW}}\right)$, Simpson's $\left(H_{\mathrm{SI}}\right)$, and Kosman's $\left(H_{\mathrm{KW}}\right.$, and $H_{\mathrm{KD}}$ iv) indices of diversity within populations (years) of Puccinia recondita f. sp. tritici

\begin{tabular}{|c|c|c|c|c|c|c|c|c|c|c|c|c|c|c|c|c|c|c|}
\hline \multirow{2}{*}{$\begin{array}{l}\text { Diversity } \\
\text { Index }\end{array}$} & \multicolumn{3}{|c|}{$1993-1997^{a}$} & \multicolumn{3}{|c|}{$1993^{\mathrm{b}}$} & \multicolumn{3}{|c|}{$1994^{\mathrm{b}}$} & \multicolumn{3}{|c|}{$1995^{\mathrm{b}}$} & \multicolumn{3}{|c|}{$1996^{\mathrm{b}}$} & \multicolumn{3}{|c|}{$1997^{\mathrm{b}}$} \\
\hline & $H_{\mathrm{KW}}$ & $H_{\mathrm{SW}}$ & $H_{\mathrm{SI}}$ & $H_{\mathrm{KW}}$ & $H_{\mathrm{SW}}$ & $H_{\mathrm{SI}}$ & $H_{\mathrm{KW}}$ & $H_{\mathrm{SW}}$ & $H_{\mathrm{SI}}$ & $H_{\mathrm{KW}}$ & $H_{\mathrm{SW}}$ & $H_{\mathrm{SI}}$ & $H_{\mathrm{KW}}$ & $H_{\mathrm{SW}}$ & $H_{\mathrm{SI}}$ & $H_{\mathrm{KW}}$ & $H_{\mathrm{SW}}$ & $H_{\mathrm{SI}}$ \\
\hline$\overline{H_{\mathrm{KDiv}}}$ & $0.995^{\mathrm{c}}$ & 0.771 & 0.686 & 1.000 & 0.919 & 0.907 & 0.969 & 0.389 & 0.084 & 0.851 & 0.144 & -0.184 & 0.999 & 0.104 & -0.056 & 0.830 & 0.823 & 0.543 \\
\hline$H_{\mathrm{KW}}$ & $\ldots$ & 0.759 & 0.669 & $\ldots$ & 0.990 & 0.907 & $\ldots$ & 0.361 & 0.091 & $\ldots$ & -0.011 & -0.418 & $\ldots$ & 0.096 & -0.064 & $\ldots$ & 0.566 & 0.166 \\
\hline$H_{\mathrm{SW}}$ & $\ldots$ & $\ldots$ & 0.964 & $\ldots$ & $\ldots$ & 0.988 & $\ldots$ & $\ldots$ & 0.894 & $\ldots$ & $\ldots$ & 0.819 & $\ldots$ & $\ldots$ & 0.942 & $\ldots$ & $\ldots$ & 0.867 \\
\hline
\end{tabular}

a Diversity indices: 50 indices for 50 random samples = 10 random samples for each of 5 years (1993 to 1997).

${ }^{\mathrm{b}}$ Diversity indices: 10 indices for 10 random samples for the corresponding year.

${ }^{c}$ Pearson correlation values.

TABLE 5. Diversities between populations (years) of Puccinia recondita f. sp. tritici in Israel during 1993 to 1997, measured by Nei's $(N)$, Rogers' $(R)$, and Kosman's $\left(H_{\mathrm{KB}}\right.$ and $\left.H_{\mathrm{KDis}}\right)$ distances

\begin{tabular}{|c|c|c|c|c|c|c|c|c|c|c|c|c|c|c|c|c|}
\hline \multirow[b]{2}{*}{ Year } & \multicolumn{4}{|c|}{1994} & \multicolumn{4}{|c|}{1995} & \multicolumn{4}{|c|}{1996} & \multicolumn{4}{|c|}{1997} \\
\hline & $N$ & $R$ & $H_{\mathrm{KB}}$ & $H_{\mathrm{KDis}}$ & $N$ & $R$ & $H_{\mathrm{KB}}$ & $H_{\mathrm{KDis}}$ & $N$ & $R$ & $H_{\mathrm{KB}}$ & $H_{\mathrm{KDis}}$ & $N$ & $R$ & $H_{\mathrm{KB}}$ & $H_{\mathrm{KDis}}$ \\
\hline 1993 & 0.072 & 0.777 & 0.207 & 0.184 & 0.060 & 0.710 & 0.164 & 0.153 & 0.046 & 0.633 & 0.142 & 0.138 & 0.081 & 0.816 & 0.189 & 0.164 \\
\hline 1994 & $\ldots$ & $\ldots$ & $\ldots$ & $\ldots$ & 0.043 & 0.810 & 0.162 & 0.140 & 0.047 & 0.726 & 0.158 & 0.149 & 0.077 & 0.936 & 0.186 & 0.175 \\
\hline 1996 & $\ldots$ & $\ldots$ & $\ldots$ & $\ldots$ & $\ldots$ & $\ldots$ & $\ldots$ & $\ldots$ & $\ldots$ & $\ldots$ & $\ldots$ & $\ldots$ & 0.080 & 0.849 & 0.169 & 0.161 \\
\hline
\end{tabular}


the changes in distances between years (populations) can be explained by the changes in differences between diversities within each of the years is raised.

The relationship between the difference in diversities within populations and the distance between populations is presented in Table 7. It provides an explanation of whether the diversity, $H_{\mathrm{KB}}$, between two populations ( $X$ and $Y$ ) can be estimated by the absolute value of difference between the diversities, $H_{\mathrm{Kw}}$, within each population. The presented results demonstrate that the variance in the diversity, $H_{\mathrm{KB}}$, between populations can be only partially explained (less than $52.8 \%$ ) by the difference between corresponding diversities within populations.

\section{DISCUSSION}

Diversity of virulence in a pathogen population is strongly affected by human-guided forces; in this case, the genes for resistance in cultivated wheat cultivars. In Israel, the indigenous wild Triticum spp., Aegilops spp. relatives, and local land races also may exert force on pathogen populations (22). These forces interact with ecological determinants, especially those associated with the agroecosystem. The structure of leaf rust populations in Israel may be influenced by the interaction between genes in different wheat species, although there is little genetic introgression between common wheat and wild emmer or land races of $T$. durum. There was a strong resemblance in virulence combinations and frequencies on different $L r$ genes between leaf rust collections sampled from common and wild emmer wheat. Both differed to a great extent from collections sampled from $T$. durum. These differences may be attributed to the "screening effect" of durum genotypes in favor of distinct durum phenotypes (BBB or $\mathrm{DBB}$ ); i.e., phenotypes with weak virulence $(3,9,13,26)$. In the in situ study of natural $T$. dicoccoides stands conducted at Ammiad, Israel, during 1985 to 1987, 100 leaf rust isolates originated from $T$. dicoccoides were evaluated on $\mathrm{Lr}$ lines (3). All isolates collected from $T$. dicoccoides in the Ammiad study were avirulent on $L r 2 a$, and most on were avirulent Lr26. The results from the Ammiad study for $T$. dicoccoides-sampled isolates differed from the findings of our study only for $L r 2 a$.

The virulence spectrum of $T$. dicoccoides-sampled isolates in our study greatly resembled that of common wheat. The most noticeable changes in the overall virulence spectrum of leaf rust in Israel since 1986 was associated with resistance genes $L r 2 a$ (cv. Webster), Lr11 (cv. Hussar), Lr15 (cv. Kenya 1483), and Lr26 (cv. Imperial rye), with no virulence detected on $\operatorname{Lr} 9$ (T. umbellulatum) and Lr24 (Agropyron elongatum) lines $(18,19,21)$. The virulence spectrum in the Israeli leaf rust populations was similar to that recorded for a survey conducted in seven European countries in 1995 (26). The European leaf rust isolates $(n=850)$, like the Israeli population, were avirulent on $\operatorname{Lr} 9, \operatorname{Lr} 19, \operatorname{Lr} 21$, and $\operatorname{Lr} 24$ and also on $L r 25$ and $L r 29$, which were not included in our study. Nazim et al. (24) reported that 221 leaf rust isolates collected in Egypt during 1993 to 1996 all carried virulence to the 17 tested $\mathrm{Lr}$ genes. Most of these $L r$ genes also were included in our study (including $L r 15$ and excluding $L r 22 b$ ). The frequency of virulence on $L r 9$ in Egypt ranged from 59.5 to $75.4 \%$ and 61.1 to $85.7 \%$ on Lr24; both are completely resistant to leaf rust in Israel. The lowest frequency in the Egyptian survey was recorded on $\operatorname{Lr} 21$ ( $T$. tauschii) (19.1 to $72.5 \%$ ) compared with 1.7 to $14.0 \%$ in the Israeli populations. The possible regional impact of the broad virulence spectrum reported in the Egyptian leaf rust populations should be considered.

The indices for measuring diversity between and within populations of a pathogen can be divided into three groups. The genetic diversity indices are Nei's $(N)$ and Kosman's ( $H_{\mathrm{KDis}}$ distances and $H_{\mathrm{KDis}}$ index), which are based on frequencies of individual virulences on differentiating hosts, in this case on $L r$ genes, without regard to phenotype. The phenotypic diversity indices are Rogers' $(R)$, Shannon-Weaver's $\left(H_{\mathrm{SW}}\right)$, and Simpson's $\left(H_{\mathrm{SI}}\right)$, which are based on the frequencies of virulence patterns of isolates on an entire set of differentials (phenotypes), regardless of how many virulences the phenotypes share. Two new indices (Kosman's $H_{\mathrm{KB}}$ distance and $H_{\mathrm{KW}}$ diversity index) are more appropriate for plant pathogens (11) because they take into account both phenotypic frequencies and degree of similarity among distinct phenotypes.

Analysis of diversity within populations of $P$. recondita $\mathrm{f}$. sp. tritici (Table 3) reveals that the four measures used do not yield the same rank order of diversity. The $H_{\mathrm{SW}}$ and $H_{\mathrm{SI}}$ indices describe changes in diversity during the years 1993 to 1997 in a similar manner. This was expected because they are phenotypic diversity indices with the same input for calculation. On the other hand, the genetic diversity index, $H_{\mathrm{KDiv}}$, displays a different picture. The $H_{\mathrm{KDiv}}$ index significantly increased from 1993 to 1994 and then decreased from 1994 to 1995, in the same manner as the phenotypic diversity indices, $H_{\mathrm{SW}}$ and $H_{\mathrm{SI}}$. $H_{\mathrm{KDiv}}$ dropped from 1995 to 1996 and did not change statistically from 1996 to 1997, whereas $H_{\mathrm{SW}}$ and $H_{\mathrm{SI}}$ increased from 1995 to 1996 and decreased from 1996 to 1997 . Thus, the genetic and phenotypic diversity indices described the evolution of the population differently. Kosman's $H_{\mathrm{KW}}$ index yielded the same rank order of diversity as the genetic diversity index, $H_{\mathrm{KDiv}}$.

TABLE 7. Relationship between distances and diversities within Puccinia recondita f. sp. tritici populations (years) in Israel during 1993 to 1997

\begin{tabular}{lcc}
\hline Comparisons $^{\mathrm{a}}$ & Correlation $^{\mathrm{b}}$ & \% Variance $^{\mathrm{c}}$ \\
\hline $1993-1997$ (all) & 0.494 & 24.4 \\
1993 vs. other years & 0.478 & 22.8 \\
1994 vs. other years & 0.727 & 52.8 \\
1995 vs. other years & 0.545 & 29.7 \\
1996 vs. other years & -0.032 & 0.1 \\
1997 vs. other years & 0.624 & 38.9
\end{tabular}

a Distances between populations (years): 100 distances for 100 paired random samples $=10$ random samples for each full set of 10 comparisons between 5 years (1993 to 1997).

b Correlation between Kosman's $H_{\mathrm{KB}}$ distance between populations $X$ and $Y$ and the difference, $\left|H_{\mathrm{KW}}(X)-H_{\mathrm{KW}}(Y)\right|$, in Kosman's diversities, $H_{\mathrm{KW}}$, within populations $X$ and $Y$.

c Percentage of variance of $H_{\mathrm{KB}}$ distance between populations explained by difference in diversities, $H_{\mathrm{KW}}$, within populations.

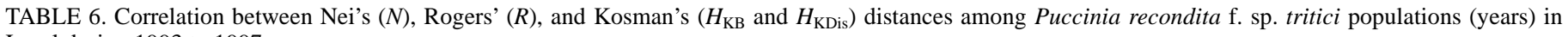
Israel during 1993 to 1997

\begin{tabular}{|c|c|c|c|c|c|c|c|c|c|c|c|c|c|c|c|c|c|c|}
\hline \multirow[b]{2}{*}{ Distance } & \multicolumn{3}{|c|}{$1993-1997^{a}$} & \multicolumn{3}{|c|}{1993 vs. other years ${ }^{b}$} & \multicolumn{3}{|c|}{1994 vs. other years ${ }^{b}$} & \multicolumn{3}{|c|}{1995 vs. other years ${ }^{b}$} & \multicolumn{3}{|c|}{1996 vs. other years ${ }^{b}$} & \multicolumn{3}{|c|}{1997 vs. other years ${ }^{b}$} \\
\hline & $H_{\mathrm{KB}}$ & $N$ & $R$ & $H_{\mathrm{KB}}$ & $N$ & $R$ & $H_{\mathrm{KB}}$ & $N$ & $R$ & $H_{\mathrm{KB}}$ & $N$ & $R$ & $H_{\mathrm{KB}}$ & $N$ & $R$ & $H_{\mathrm{KB}}$ & $N$ & $R$ \\
\hline$\overline{H_{\mathrm{KDis}}}$ & $0.936^{\mathrm{c}}$ & 0.851 & 0.393 & 0.943 & 0.894 & 0.735 & 0.926 & 0.943 & 0.337 & 0.901 & 0.832 & -0.148 & 0.962 & 0.834 & 0.590 & 0.590 & 0.838 & 0.140 \\
\hline$H_{\mathrm{KB}}$ & $\ldots$ & 0.835 & 0.494 & $\ldots$ & 0.873 & 0.856 & $\ldots$ & 0.859 & 0.322 & $\ldots$ & 0.768 & 0.107 & $\ldots$ & 0.869 & 0.710 & $\ldots$ & 0.812 & 0.077 \\
\hline$N$ & $\ldots$ & $\ldots$ & 0.552 & $\ldots$ & $\ldots$ & 0.779 & $\ldots$ & $\ldots$ & 0.525 & $\ldots$ & $\ldots$ & 0.077 & $\ldots$ & $\ldots$ & 0.780 & $\ldots$ & $\ldots$ & -0.046 \\
\hline
\end{tabular}

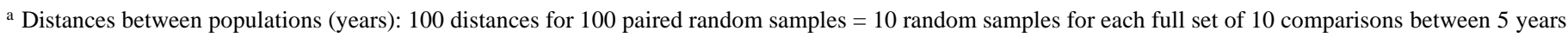
(1993 to 1997).

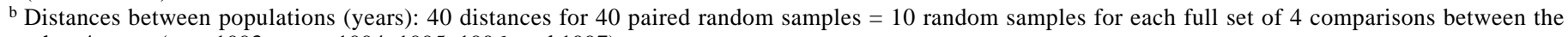
other 4 years (e.g., 1993 versus 1994, 1995, 1996, and 1997).

c Pearson correlation values. 
The described tendencies of changes in diversity indices were confirmed by the study of relationships between different indices (Table 4). Shannon-Weaver's and Simpson's indices were highly correlated, whereas correlations between the genetic index, $H_{\mathrm{KDiv}}$, and phenotypic indices, $H_{\mathrm{SW}}$ and $H_{\mathrm{SW}}$, were small (except for 1993) or even negative, indicating that the variance of phenotypic structure of populations cannot be satisfactorily explained by the virulence structure (except for the 1993 population).

Kosman's diversity index, $H_{\mathrm{KW}}$, was highly correlated with the genetic index, $H_{\mathrm{KDiv}}$ (Table 4$)$, but correlations between $H_{\mathrm{KW}}$ and Shannon-Weaver's and Simpson's indices were low (except for 1993). Therefore, the variance of diversity within Israeli leaf rust populations in 1993 to 1997 was almost fully explained by genetic diversity and can be explained by phenotypic diversity only for the 1993 population.

Müller et al. (23) recently developed a new measure of diversity within a pathogen population, $D$, that is termed the mean dissimilarity. The $D$ index is the mean number of virulence loci differences between all pairs of different isolates in a sample (population). One can show that:

$$
D=\frac{2 n}{k(n-1)} \sum_{i=1}^{k} p_{i}\left(1-p_{i}\right)
$$

where $p_{\mathrm{i}}$ is the virulence frequency of a given population on differential $i, k$ is the total number of differentials, and $n$ is the total number of isolates in the sample. Therefore, according to our terminology, the mean dissimilarity is an index of genetic diversity.

Müller et al. (23) demonstrated that mean dissimilarity $(D)$ is indicative of obvious differences between two samples (populations), whereas under these conditions both Shannon-Weaver's entropy $\left(H_{\mathrm{SW}}\right)$ and Simpson's index $\left(H_{\mathrm{SI}}\right)$ are equal. The usefulness of Kosman's $H_{\mathrm{KW}}$ and $H_{\mathrm{KDiv}}$ diversities is demonstrated in the following example: two samples consist of four isolates, identified by virulence $(\mathrm{V})$ or avirulence $(\mathrm{A})$ at four loci. The first sample consists of pathotypes VAAA, AVAA, AAVA, and AAAV, and the second sample consists of VVAA, AVAA, AAAV, and VAAV. The $H_{\mathrm{KW}}$ and $H_{\mathrm{KDiv}}$ diversity indices of 0.5 were calculated for the first sample, and a higher (0.75) level of diversity was calculated for the second population. Neither the mean dissimilarity $(D)$ nor the $H_{\mathrm{SW}}$ and $H_{\mathrm{SI}}$ diversity indices differentiated between these populations $\left(D=0.5, H_{\mathrm{SW}}=1 \mathrm{n}(4)\right.$, and $\left.H_{\mathrm{SI}}=0.75\right)$, whereas the $H_{\mathrm{KW}}$ and $H_{\text {KDiv }}$ did distinguish between them.

The study of diversity among Israeli leaf rust populations (years) from 1993 to 1997 (Table 5) resulted in the conclusion that the trends of change are not generally similar when Nei's $(N)$, Rogers' $(R)$, and Kosman's $\left(H_{\mathrm{KB}}\right.$ and $\left.H_{\mathrm{KDis}}\right)$ distances are applied. As mentioned previously, maximal and minimal values of the given distances were not obtained for the same pairs of population (Table 5). For example, consider the chain of distances between consecutive years, 1993, 1994, 1995, 1996, and 1997. The corresponding series of the genetic distances $N$ and $H_{\text {KDis }}$ are $0.072 \backslash 0.043 \backslash 0.038 / 0.080$ and $0.184 \backslash 0.140 \backslash 0.129 / 0.161$, respectively. These distances tend to change in agreement. On the other hand, Rogers' phenotypic distance shows a different rank order of $0.777 / 0.810 \backslash 0.734 / 0.849$. This can be explained by the fact that Nei's and Kosman's $H_{\mathrm{KDis}}$ distances are of a similar nature, whereas Rogers' distance is not. Kosman's distance, $H_{\mathrm{KB}}$, yields the same rank order as genetic distances $H_{\mathrm{KDis}}$ and $N: 0.207 \backslash 0.162 \backslash 0.141 / 0.169$.

In general, genetic distances $N$ and $H_{\text {KDis }}$ were relatively highly correlated (Table 6), whereas correlations between either of them and Rogers' phenotypic distance were low. This means that the variance of difference between phenotypic structures of $P$. recondita f. sp. tritici populations in 1993 to 1997 , measured by Rogers' distance, cannot be explained only by the difference between the virulence structures of the given populations measured by the genetic distances.

Kosman's distance, $H_{\mathrm{KB}}$, was highly correlated with genetic distances $H_{\mathrm{KDis}}$ and $N$ but had only a low correlation with the phe- notypic distance $R$ (Table 6). Two exceptions were the 1993 and 1997 populations versus the other populations. In the first case (1993 versus other years), the correlation between $H_{\mathrm{KB}}$ and Rogers' distances was relatively high, and in the second (1997 versus other years), the correlation between $H_{\mathrm{KB}}$ and $H_{\mathrm{KDis}}$ distances was very low. Therefore, diversity between Israeli leaf rust populations in 1993 to 1997 , as expressed by Kosman's $H_{\mathrm{KB}}$ distance, can be predicted primarily by genetic diversities $H_{\mathrm{KDis}}$ and $N$.

The analysis of diversity between populations (expressed by the $H_{\mathrm{KB}}$ distance) compared with changes in diversity within populations (expressed by the $H_{\mathrm{KW}}$ index) revealed an insignificant level of correlation between them (Table 7). Therefore, the diversity between Israeli populations of $P$. recondita f. sp. tritici in 1993 to 1997 cannot be predicted only by the difference between corresponding diversities within populations. Other parameters, in addition to diversity within populations, may have an influence on the difference between given populations. One such parameter could be a measure of the overall linkage between genes, which probably could be developed on the basis of virulence patterns corresponding to each differential across all ordered sets of sample isolates.

Our study of diversities between $\left(H_{\mathrm{KB}}\right)$ and within $\left(H_{\mathrm{KW}}\right)$ the 1993 to 1997 Israeli leaf rust populations (years) provided insight into the dynamics of $P$. recondita $\mathrm{f}$. sp. tritici. The 1993 population, which expressed a relatively low diversity within, had undergone a marked qualitative change in 1994, including a drastic increase in $H_{\mathrm{KW}}$. The changes between the following years were moderate, and the diversities within years decreased, reaching stability in 1996 and 1997 at a higher level than that of 1993. This change in diversity may have resulted from the sporadic disease incidence in 1993, reflecting a special case. It is possible that diversity within the years prior to 1993 was at level similar to that of 1996 and 1997, and the decrease that occurred in 1993 attained an elevated and balanced level several years later. There were no major changes in wheat cultivar profiles in the wheat-management system that can explain this change. The influx of primary inoculum from neighboring countries with little rust development into Israel may have contributed to the change in the structure of the Israeli leaf rust population in 1993. A marked change in the virulence spectrum of yellow rust ( $P$. striiformis) has occurred with the introduction into northern Israel in 1994 of $\operatorname{Yr} 9$ virulence, which spread south in a wide distribution patteran and has persisted in the population ever since (21). Finally, the comparison of diversity indices based on the leaf rust data suggests that Kosman's indices are theoretically informative and useful tools in population genetics studies.

\section{NOTE}

Puccinia recondita f. sp. tritici was referred to as Puccinia triticina by Anikster et al (1).

\section{ACKNOWLEDGMENTS}

Supported in part by Israel's Field Crop Commission.

\section{LITERATURE CITED}

1. Anikster, Y., Bushnell, W. R., Eilam, T., Manisterski, J., and Roelfs, A. P. 1997. Puccinia recondita causing leaf rust on cultivated wheats, wild wheats and rye. Can. J. Bot. 75:2082-2090.

2. Browder, L. E. 1980. A compendium of information about named genes for low reaction to Puccinia recondita in wheat. Crop Sci. 20:775-779.

3. Dinoor, A., Eshed N., Ecker, R., Gerechter-Amitai, Z., Solel, Z., Manisterski, J., and Anikster, Y. 1991. Fungal diseases of wild tetraploid wheat in a natural stand in northern Israel. Isr. J. Bot. 40:481-500.

4. Dyck, P. L., and Johnson, R. 1983. Temperature sensitivity of genes for resistance in wheat to Puccinia recondita. Can. J. Plant Pathol. 5:229-234.

5. Dyck, P. L., and Samborski, D. J. 1968. Genetics of resistance to leaf rust 
in the common wheat varieties Webster, Loros, Brevit, Carina, Malakof and Centenario. Can. J. Genet. Cytol. 10:7-17.

6. Dyck, P. L., and Samborski, D. J. 1968. Host-parasite interactions involving genes for leaf rust resistance in wheat. Pages 245-250 in: Proc. 3rd Int. Wheat Genet. Symp. K. W. Finlay and K. W. Shepherd, eds. Australian Academy of Science, Canberra, Australia.

7. Groth, J. V., and Roelfs, A. P. 1987. The concept and measurement of phenotypic diversity in Puccinia graminis on wheat. Phytopathology 77: 1395-1399.

8. Groth, J. V., and Roelfs, A. P. 1987. Analysis of virulence diversity in populations of plant pathogens. Pages 63-74 in: Populations of Plant Pathogens. M. S. Wolfe and C. E. Caten, eds. Blackwell Scientific Publications, Palo Alto, CA.

9. Huerta-Espino, J. 1992. Analysis of wheat leaf and stem rust virulence on a worldwide basis. Ph.D. thesis. University of Minnesota, St. Paul.

10. Kolmer, J. A. 1991. Phenotypic diversity in two populations of Puccinia recondita f. sp. tritici in Canada during 1931-1987. Phytopathology 81:311-315.

11. Kosman, E. 1996. Difference and diversity of plant pathogen populations: A new approach for measuring. Phytopathology 86:1152-1155.

12. Leonard, K. J., Roelfs, A. P., and Long, D. L. 1992. Diversity of virulence within and among populations of Puccinia recondita $\mathrm{f}$. $\mathrm{sp}$. tritici in different areas of the United States. Plant Dis. 76:500-504.

13. Long, D. L., and Kolmer, J. A. 1989. A North American system of nomenclature for Puccinia recondita f. sp. tritici. Phytopathology 79:525529.

14. Long, D. L., Leonard, K. J., and Roberts, J. J. 1998. Virulence and diversity of wheat leaf rust in the United States in 1993 to 1995. Plant Dis. 82:1391-1400.

15. Long, D. L., Roelfs, A. P., Leonard, K. J., and Roberts, J. J. 1993. Virulence and diversity of Puccinia recondita f. sp. tritici in the United States in 1991. Plant Dis. 77:786-791.

16. Long, D. L., Roelfs, A. P., Leonard, K. J., and Roberts, J. J. 1994. Virulence and diversity of Puccinia recondita f. sp. tritici in the United States in 1992. Plant Dis. 78:901-906.

17. Long, D. L., Roelfs, A. P., and Roberts, J. J. 1992. Virulence of Puccinia recondita f. sp. tritici in the United States during 1988-1990. Plant Dis. 76:495-499.
18. Manisterski, J. 1990. Changes in virulence spectrum of Puccinia recondita tritici, the casual agent of leaf rust of wheat. Phytoparasitica 18:76-77.

19. Manisterski, J., Ben-Yehuda, P., Bar, E., and Eyal, Z. 1995. Wheat rust survey in Israel in 1994. Phytoparasitica 23:250-251.

20. Manisterski, J., Ben-Yehuda, P., Eyal, Z., Eilam, T., and Anikster, Y. 1998. Appearance in natural habitat of a leaf rust on a population of Aegilops speltoides in Israel. Phytoparasitica 26:158.

21. Manisterski, J., Kosman, E., and Eyal, Z. 1996. Changes in wheat leaf rust and yellow rust populations in Israel. Page 140 in: Proc. 9th Eur. Mediterr. Rusts Powdery Mildews Conf. G. H. J. Kema, R. E. Niks, and R. A Daamen, eds. Cereal Rusts Powdery Mildews Bull. Vol. 24, Suppl. 1996. Wageningen, Netherlands.

22. Manisterski, J., Segal, A., Levy, A. A., and Feldman, M. 1988. Evaluation of Israeli Aegilops and Agropyron species for resistance to wheat leaf rust. Plant Dis. 72:941-944.

23. Müller, K., McDermott, J. M., Wolfe, M. S., and Limpert, E. 1996. Analysis of diversity in populations of plant pathogens: The barley powdery mildew pathogen across Europe. Eur. J. Plant Pathol. 102:385-395.

24. Nazim, M., Sharif, S., Nasr, M., and Shahin, S. 1998. Shift of virulences in wheat leaf rust population in Egypt during 1993-1996. Proc. 7th Int. Congr. Plant Pathol. Edinburgh.

25. Nei, M. 1972. Genetic distance between populations. Am. Nat. 106:283292.

26. Park, R. F., and Felsenstein, F. G. 1998. Physiological specialization and pathotype distribution of Puccinia recondita in western Europe, 1995. Plant Pathol. 47:157-164.

27. Roelfs, A. P., Singh, R. P., and Saari, E. E. 1992. Rust diseases of wheat: Concepts and methods of disease management. International Maize and Wheat Improvement Center, Mexico, D.F.

28. Rogers, J. S. 1972. Measures of genetic similarity and genetic distance. Pages 145-153 in: Studies in Genetics. University of Texas, Austin.

29. Shannon, C. E., and Weaver, W. 1949. The Mathematical Theory of Communication. University of Illinois Press, Urbana.

30. Simpson, E. H. 1949. Measurement of diversity. Nature 163:688.

31. Singh, R. P. 1991. Pathogenicity variations of Puccinia recondita f. sp. tritici and $P$. graminis f. sp. tritici in wheat-growing areas of Mexico during 1988 and 1989. Plant Dis. 75:790-794. 